\title{
SELF-MEDICATION PRACTICES AMONG THE PATIENTS WITH CHRONIC VENOUS DISEASE
}

\author{
IVANA DAMNJANOVIC $^{1 *}$, NIKOLA STEFANOVIC ${ }^{1}$, SNEZANA ZLATKOVIC-GUBERINIC ${ }^{2}$, \\ ZORAN DAMNJANOVIC ${ }^{3}$, ALEKSANDRA CATIC-DJORDJEVIC ${ }^{1}$, RADMILA VELICKOVIC- \\ RADOVANOVIC ${ }^{1}$
}

${ }^{1}$ Department of Pharmacy, Faculty of Medicine, University of Nis, 81 Dr Zorana Djindjica Boulevard, 18000, Nis, Serbia

${ }^{2}$ Health Care Institution Pharmacy Remedia Nis, 2 Obrenoviceva Street, 18000, Nis, Serbia

${ }^{3}$ Clinic of Vascular Surgery, Clinical Centre of Nis, 48 Dr Zorana Djindjica Boulevard, 18000, Nis, Serbia

*corresponding author: ivana.damnjanovic@medfak.ni.ac.rs

Manuscript received: June 2019

\begin{abstract}
Pharmacotherapeutic strategies in the treatment of chronic venous disease (CVD) include a wide range of venoactive drugs available in the form of over the counter medicines and dietary supplements. The aim of this study was to investigate selfmedication practice concerning the relative influence of health care professionals and self-initiative on the choice of pharmacotherapy treatment of CVD symptoms. The conducted cross-section epidemiological study showed a high presence of venoactive drugs among patients with CVD symptoms, and also implied the attendance of the self-initiative use of venoactive drugs in $35.6 \%$ respondents suffering from CVD. There was a statistically significant difference between the groups of respondents in relation to the relative influence of physician, pharmacist and self-initiative on the choice of pharmacotherapy treatment of CVD symptoms regarding the nature and route of drug administration. According to this, it is important to have data on self-medication in this area, so that future interventions can be planned.
\end{abstract}

\section{Rezumat}

Strategiile farmacoterapeutice în tratamentul bolilor venoase cronice (BVC) includ o gamă largă de medicamente venoactive disponibile sub formă de medicamente OTC și suplimente alimentare. Scopul acestui studiu a fost de a investiga practicile de auto-medicație privind influența relativă a profesioniștilor din domeniul sănătății și auto-inițiativa asupra alegerii tratamentului farmacoterapeutic al simptomelor BVC. Studiul epidemiologic efectuat a arătat o prevalență ridicată a medicamentelor venoactive în rândul medicației pacienților cu simptome de BVC și a implicat, de asemenea, utilizarea prin autoinițiativă de medicamente venoactive la $35,6 \%$ dintre respondenții care suferă de BVC. A existat o diferență semnificativă statistic între grupurile de respondenți în raport cu influența relativă a medicului, farmacistului și a autoinițiativei în alegerea tratamentului farmacoterapeutic al simptomelor BVC în ceea ce privește natura şi calea de administrare a medicamentului. Conform acestui fapt, este important să existe date despre auto-medicație în acest domeniu, pentru a putea planifica intervențiile viitoare.

Keywords: self-medication, chronic venous diseases, venoactive drug

\section{Introduction}

Chronic venous disease (CVD) is by definition "a set of morphological and functional abnormalities of the venous system of long duration, manifested by symptoms or signs or both, indicating the need for investigation and/or care" [15]. This is a common condition with a major impact on the health-care system due to its high prevalence (25-40\% and $10-20 \%$ in women and men, respectively), not to mention the human impact in terms of worsened quality of life [2]. The signs of CVD in the legs are variable and included a broad range of symptoms and signs associated with primary CVD, the most obvious of which are varicose veins and venous leg ulcers, but which also include oedema and skin changes [25]. In addition to age and sex, the main risk factors considered included lifestyle and occupation, number of pregnancies, family history and geographic influences [31]. Medical treatment of CVD involves lifestyle changes and compression therapy, the use of pharmacotherapy including venoactive drugs (VADs) or advanced surgical methods $[4,23]$. The principle for the use of venoactive drugs implies improving the venous tone and capillary permeability, although most of these drugs still don`t have completely known or precise mechanisms of action [16].

Pharmacotherapeutic strategies in the treatment of CVD include a wide range of venoactive drugs. VADs are a heterogeneous group of plant-based or synthetic drug $[16,25]$. The most studied are flavonoids and saponins extracted from plants which are widely used and available in the form of over the counter (OTC) medicines and dietary supplements (Table I). 
Classification of the main venoactive drugs described in the paper

\begin{tabular}{|l|c|c|c|}
\hline \multirow{2}{*}{ Compound/substance } & \multicolumn{3}{|c|}{ Type of product } \\
\cline { 2 - 4 } & Prescriptions & OTC & Dietary supplement \\
\hline Diosmin & - & + & - \\
\hline Troxerutin & - & + & + \\
\hline Aescin & - & + & + \\
\hline Ginkgo biloba extracts & - & + & + \\
\hline Heparin & - & + & - \\
\hline Gland extract of medicinal leeches & - & - & + \\
\hline
\end{tabular}

Self-medication is still a global public health problem, since it has become very common in pharmaceutical practice [7]. The importance of self-medication as a phenomenon has attracted the interest of health professionals including physicians and pharmacist, especially for OTC drugs which can be sold without prescription [3]. The aim of this study was to investigate self-medication practice concerning the relative influence of health care professionals and self-initiative on the choice of pharmacotherapy treatment of CVD symptoms.

\section{Materials and Methods}

A cross-sectional epidemiological study was conducted in 6 Remedia Pharmacy Health Facilities on the territory of Nis (South Serbia) from October through December 2017. Study was performed using an anonymous questionnaire, with closed-ended questions and different variants of dichotomous ones, to those combined with open-ended questions. All questionnaires were completed anonymously, on a voluntary basis and an informed consent was obtained from each patient for being included in the study. To reduce the risk of the bias, one pharmacist per pharmacy conducted survey with respondents by face-to-face interview. The researcher asked the respondent a series of questions and noted their responses. In order to protect patient data, each patient was assigned a code at the beginning of the study, which was used in statistical analysis instead of his personal name and surname. Upon that one researcher gather all the data. The criterion set for the study was to include outpatients diagnosed with chronic venous diseases who used pharmacotherapy to treat the symptoms of CVD. The exclusion criterion in the conducted research implied patients with vein ulcerations. The study enrolled 536 patients with CVD symptoms who were interviewed. Of all patients, 81 were not included in the study due to insufficient data gathered during interview (skip questions and/or did not wish to answer) or they were excluded from the examination due to the exclusion criterion. Finally, 455 of the total respondents with
CVD symptoms provided complete data from the survey.

The survey was divided into two parts. In the first part, the questions were related to the personal data of patients (sex, age and pharmacological groups of drugs the patients used in the treatment of CVD). The second part of the survey was related to the frequency of medicaments used and the influence of both health care professionals' advice (doctors, pharmacists) and the media (television, radio, the internet) on the choice of pharmacotherapy treatment. The analysed pharmacotherapy treatment was based on the use of oral or topical medicaments with diosmin, troxerutin, aescin, Ginkgo biloba extracts, heparin and gland extract of medicinal leeches.

Data obtained from the questionnaires were statistically analysed and processed by using descriptive statistics as well as appropriate tests of statistical significance (chi-square test of independence), illustrated with tables and graphs. The database was created in an Excel statistical program, and for statistical processing, SPSS 20.0 was applied. All statistical tests would be accepted if the null hypothesis was equal to or less than $5 \%$.

\section{Results and Discussion}

The presented study provided the opportunity to examine the influence of self-medication practice in patients with CVD and the findings represent a detailed characterization of this phenomenon adding to the limited information and contributing to the existing literature data. The conducted research showed a high presence of VADs among patients with CVD symptoms.

The conducted research included $281(61.76 \%)$ women and $174(38.24 \%)$ men, aged from 18 to 86 years (median: 55 years; average: $54.49 \pm 13.95$ ). In order to investigate the self-medication practice among patients with chronic venous diseases, we analysed the relative influence of physicians, pharmacists and self-initiative on bringing decision on pharmacotherapy for treating CVD symptoms according to the sex and age categories (Table II). 
Table II

Presentation of respondents according to the sex and age in relation to bringing decision on pharmacotherapy

\begin{tabular}{|c|c|c|c|c|}
\hline Respondents characteristics & Physicians & Pharmacists & Self-initiative & Total \\
\hline$A G E(Y E A R S)$ & $\mathbf{N}(\%)$ & $\mathbf{N}(\%)$ & $\mathbf{N}(\%)$ & $\mathbf{N}(\%)$ \\
\hline$<45$ & $36(35.64 \%)$ & $37(36.63 \%)$ & $28(27.73 \%)$ & $101(100 \%)$ \\
\hline $45-64$ & $79(35.91 \%)$ & $58(26.36 \%)$ & $83(37.73 \%)$ & $220(100 \%)$ \\
\hline$>64$ & $48(35.82 \%)$ & $35(26.12 \%)$ & $51(38.06 \%)$ & $134(100 \%)$ \\
\hline \multicolumn{5}{|l|}{ GENDER } \\
\hline Male & $64(36.78 \%)$ & $47(27.01 \%)$ & $63(36.21 \%)$ & $174(100 \%)$ \\
\hline Female & $99(35.23 \%)$ & $83(29.54 \%)$ & $99(35.23 \%)$ & $281(100 \%)$ \\
\hline
\end{tabular}

There was no statistically significant difference between the age and sex groups of respondents in relation to opting for pharmacotherapy treatment of CVD symptoms. The group of respondents younger than 45 years old followed the recommendation and advice of their pharmacists for pharmacotherapy treatment of CVD symptoms, while self-initiative in the use of venoactive medications was mainly marked in the group of respondents between 45 and 64. Male respondents treated CVD symptoms most frequently according to the physicians' advice, while female respondents mostly followed the pharmacists' advice. Out of the total of 455 surveyed men and women with CVD symptoms, 162 of respondents used venoactive drugs on self-initiative $(35.61 \%)$. $30.77 \%$ of respondents were mostly influenced by media (TV, radio, Internet) in making decisions about applying medications for treating CVD symptoms, while the relative influence of family and friends in bringing this decision was the least significant (4.84\% of total respondents). Selfinitiative in the use of pharmacotherapy treatment of CVD symptoms was primarily marked in the group of female respondents $(61.76 \%)$ (Table II), and our results matched the literature data where a greater probability of self-medication was observed among women $[10,11]$.

Today, many drugs are dispensed over the counter without medical direction and/or prescription. In this case, patients prefer self-medication practice to medicate their common health problems in easier, cost effective, and times efficient manage way [21, 30]. However, the increased access to non-prescription medicines may encourage patients to believe that there is a drug treatment safe for every condition, although the consumption of OTC medications always involves some degree of danger to the consumer [28]. These data can be one of the key explanations of increased frequency of self-initiative decisions in the group of respondents with CVD symptoms. In a study conducted in Poland, similar results were recorded [33]. The study conducted in Italy by Garofalo et al. showed that the main source of information on the use of medicines were physicians followed by pharmacists (39.9\%), but there were also respondents influenced by the media (21\%) [17]. Health news and marketing activities of pharmaceutical companies reporting in the media encourage the use of medications and OTC products, ignoring the fact that prospective customers may have little knowledge about the products [13]. The media plays an important role in taking health risks, thus, the media competence is important for enhancing the risk competence of patients [29].

The influence of physicians, pharmacists and selfinitiative on the choice of pharmacotherapy treatment of CVD symptoms according to the route of drug administration is shown in Figure 1.

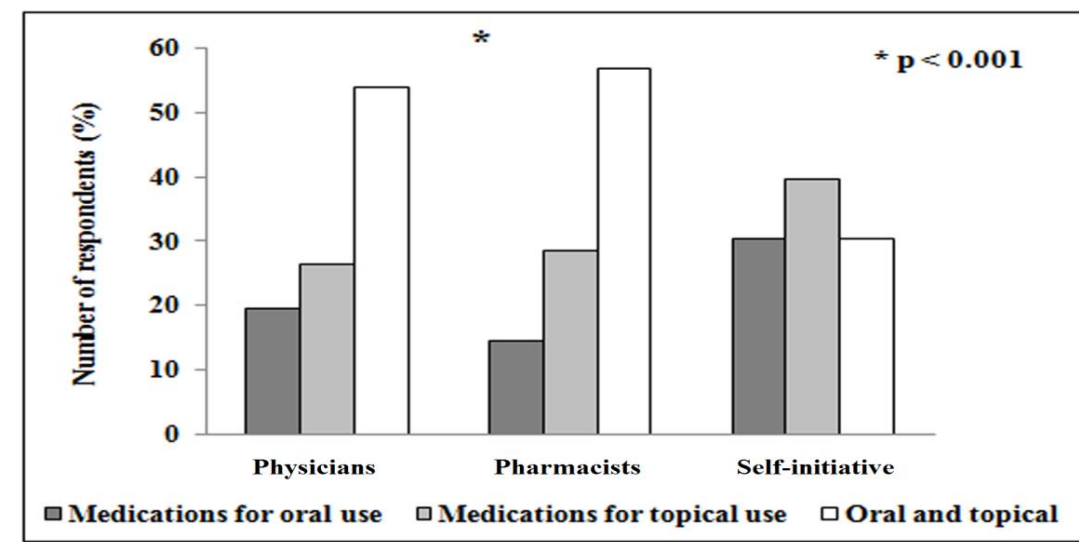

Figure 1.

The relative influence of physicians, pharmacists and self-initiative on the choice of pharmacotherapy treatment of CVD symptoms according to the route of drug administration 
The relative frequency distributions of medication choice regarding the route of drug administration differed significantly with respect to the origin of medical advice obtained by the patients with CVD symptoms $\left(\chi^{2}=27.904, \mathrm{p}<0.001\right)$. The conducted research showed that physicians and pharmacists have similar influence on opting for the route of drug administration for CVD symptoms and they usually advised combined use of oral and topical venoactive medications. In the group of respondents who selfinitiatively used the preparations for CVD symptoms, the most common were preparations for topical use (Figure 1). These results may be explained by considering the patient's belief that medicines for topical application are absolutely safe and justified. In the research conducted by Urbanek et al. $39 \%$ of patients with CVD used topical medications to relieve the symptoms [33]. An interesting point is that the same group of authors indicated that only $36 \%$ of the respondents who confirmed the existence of the above symptoms potentially associated with CVD, had completed an appointment with a doctor, whereas $23 \%$ of them had received assistance from a pharmacist [33]. However, guidelines for the treatment of CVD confer that parallel use of oral and topical venoactive medications achieve the best therapeutic effect [35]. In addition, literature data show that parallel use of topical and oral preparations with venoactive compounds lead to better reduction of heaviness, pain, local oedema and blue discoloration [32].

The second part of the survey refers to the relative frequency distribution differences regarding the nature of medication chosen by the patients, administered per os or topically, with respect, again, to the origin of medical advice. Total number of patients who used medication for oral or topical use according to their composition is shown in Figure 2.

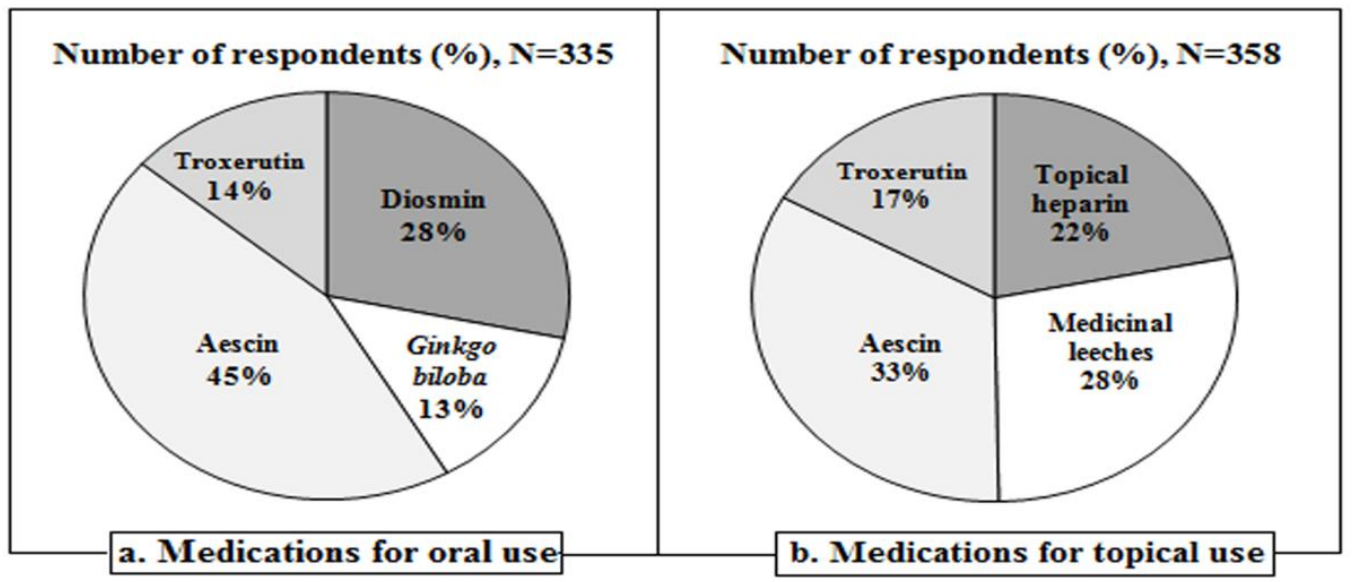

Figure 2.

Total number of patients who used medication for oral or topical use according to their composition

In our research we followed the use of venoactive drugs available in Serbia and analysed pharmacotherapy treatment based on the use of oral or topical medicaments with diosmin, troxerutin, aescin, Ginkgo biloba extracts, extracts, heparin and gland extract of medicinal leeches. Patients with CVD more frequently used oral medications based on aescin, whereas oral preparations based on Ginkgo biloba extracts were used in $13 \%$ of surveyed men and women with CVD symptoms. The conducted research indicated that the most frequently used topical medications were medications based on aescin (33\%), while the prepartions based on troxerutin were the least used (17\%) (Figure 2).

VADs can be defined as heterogeneous group of synthetic or plant-based drugs that act on capillary permeability or venous tone and may therefore have a beneficial effect in patients with CVD symptoms $[18,27]$. Venoactive drugs have been available for the treatment of varicose veins symptoms and more advanced forms of CVD for decades [26] however, their mechanism of action has not been fully elucidated [24]. Numerous studies have shown that VADs can have anti-oedema, anti-inflammatory, blood vessel protective, and venotonic activity in order to alleviate pain, heaviness, nocturnal cramps, itching and oedema in the legs and improve the quality of life of patients with CVD symptoms [6, 14, 24, 34]. Recent guidelines have reviewed the position of venoactive drugs in the management of CVD [4], and the clinical efficacy of these venoactive drugs has been evaluated in a number of clinical studies [1, 12, 14, 20].

The relative influence of physicians, pharmacists and self-initiative on the choice of pharmacotherapy treatment of CVD symptoms regarding the nature of medication is shown in Figure 3. 


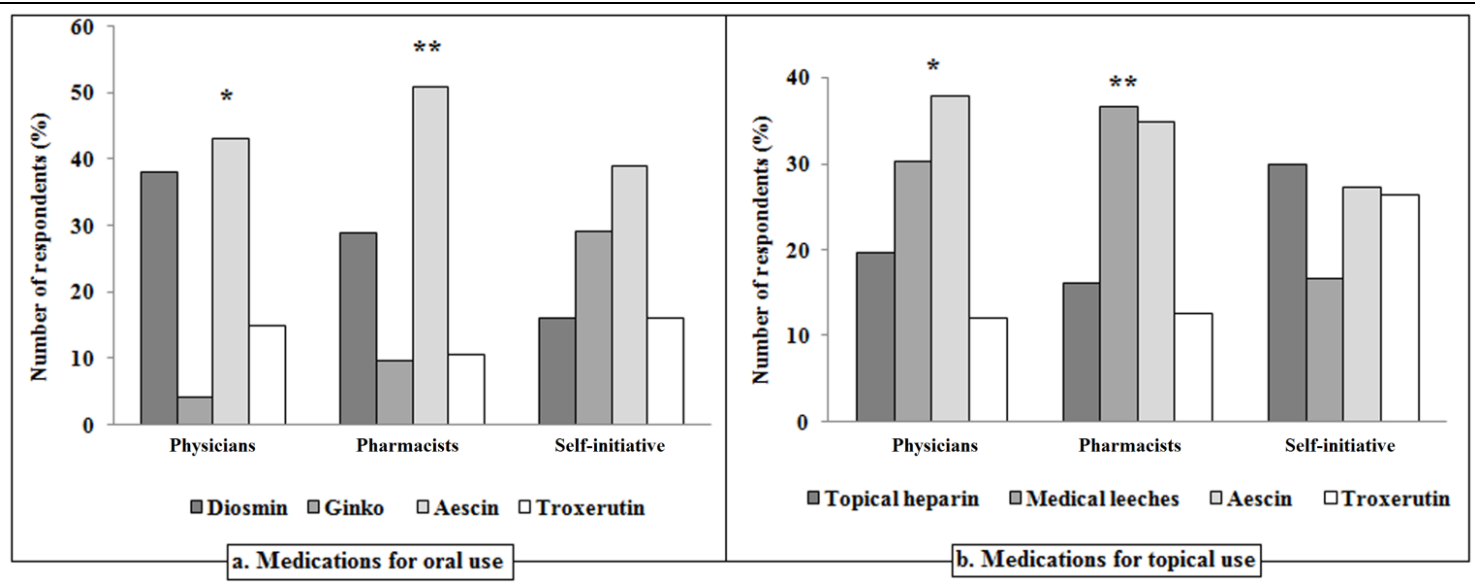

Figure 3.

The frequency of the use of medications for CVD symptoms regarding the nature of medication (*: Physician vs. Self-initiative, $\mathrm{p}<0.001 ; * *$ : Pharmacist $v s$. Self-initiative, $\mathrm{p}<0.002$ )

In both cases the choices patients made under the relative influence of physicians or pharmacists were very similar, but they differed significantly (physician $\left(\chi^{2}=31.723, \mathrm{p}<0.001\right)$ and pharmacist $\left(\chi^{2}=14.411\right.$, $\mathrm{p}<0.002)$ ) from the choices made by respondents who used venoactive drugs on self-initiative. There was a statistically significant difference between the groups of respondents in relation to the relative influence of healthcare professionals (physician $\left(\chi^{2}=16.028\right.$, $\mathrm{p}<0.001)$ and pharmacist $\left.\left(\chi^{2}=19.706, \mathrm{p}<0.001\right)\right)$ and self-initiative on the choice of topical pharmacotherapy treatment of CVD symptoms. In the study conducted in Poland by Barański et al. the most popular medicaments used for CVD were diosmin and Ruscus aculeatus extracts [5]. In Italy, Marone et al. mentioned that more than $80 \%$ of the respondents with CVD used bioflavonoides [22], while the results from the conducted research showed that the most frequently used medications were medications based on active constituents of horse chestnut seed extract (Figure 2a, Figure 3a). The largest numbers of available OTC preparations used in Serbian pharmacies for the treatment of CVD symptoms are based on chestnut extract therefore that may be one of explanation of the obtained results.

The frequency of the use of medications for CVD symptoms according to sex and age categories are shown in Table III.

Table III

The frequency of the use of medications for CVD symptoms according to sex and age categories

\begin{tabular}{|c|c|c|c|c|c|c|c|c|c|c|}
\hline \multicolumn{11}{|c|}{ ALL RESPONDENTS } \\
\hline \multicolumn{5}{|c|}{ ORAL MEDICATION } & \multicolumn{6}{|c|}{ TOPICAL MEDICATION } \\
\hline $\begin{array}{c}A G E \\
(Y E A R S)\end{array}$ & $\begin{array}{c}\text { Diosmin } \\
(\%)\end{array}$ & $\begin{array}{c}\text { Ginkgo } \\
\text { biloba } \\
(\%)\end{array}$ & $\begin{array}{c}\text { Escin } \\
(\%)\end{array}$ & $\begin{array}{c}\text { Troxerutin } \\
(\%)\end{array}$ & $\begin{array}{l}\text { Total } \\
(\%)\end{array}$ & $\begin{array}{c}\text { Topical } \\
\text { heparin } \\
(\%)\end{array}$ & $\begin{array}{c}\text { Medicinal } \\
\text { leeches } \\
(\%)\end{array}$ & $\begin{array}{c}\text { Topical } \\
\text { escin } \\
(\%)\end{array}$ & $\begin{array}{c}\text { Topical } \\
\text { troxerutin } \\
(\%)\end{array}$ & $\begin{array}{c}\text { Total } \\
(\%)\end{array}$ \\
\hline$<45$ & 38.0 & 12.7 & 35.2 & 14.1 & 100 & 18.7 & 28.0 & 38.7 & 14.7 & 100 \\
\hline $45-64$ & 30.5 & 14.9 & 42.9 & 11.7 & 100 & 23.9 & 29.5 & 30.7 & 15.9 & 100 \\
\hline$>64$ & 23.3 & 14.4 & 42.2 & 20.0 & 100 & 20.6 & 26.2 & 34.6 & 18.7 & 100 \\
\hline \multicolumn{11}{|l|}{ GENDER } \\
\hline Male & 30.8 & $\mathbf{1 7 . 5}$ & 40.8 & 10.8 & 100 & 25.8 & 29.5 & 28.0 & 16.7 & 100 \\
\hline Female & 29.7 & 12.3 & 41.0 & 16.9 & 100 & 19.5 & 27.4 & 36.7 & 16.4 & 100 \\
\hline \multicolumn{11}{|c|}{ SELF-INITIATIVE RESPONDENTS } \\
\hline & \multicolumn{4}{|c|}{ ORAL MEDICATION } & \multicolumn{6}{|c|}{ TOPICAL MEDICATION } \\
\hline $\begin{array}{c}A G E \\
(Y E A R S)\end{array}$ & $\begin{array}{c}\text { Diosmin } \\
(\%)\end{array}$ & $\begin{array}{c}\text { Ginkgo } \\
\text { biloba } \\
(\%)\end{array}$ & $\begin{array}{c}\text { Escin } \\
(\%)\end{array}$ & $\begin{array}{c}\text { Troxerutin } \\
(\%)\end{array}$ & $\begin{array}{l}\text { Total } \\
(\%)\end{array}$ & $\begin{array}{c}\text { Topical } \\
\text { heparin } \\
(\%)\end{array}$ & $\begin{array}{c}\text { Medicinal } \\
\text { leeches } \\
(\%)\end{array}$ & $\begin{array}{c}\text { Topical } \\
\text { escin } \\
(\%)\end{array}$ & $\begin{array}{c}\text { Topical } \\
\text { troxerutin } \\
(\%)\end{array}$ & $\begin{array}{c}\text { Total } \\
(\%)\end{array}$ \\
\hline$<45$ & 25 & 35 & 30 & 10 & 100 & 44.44 & 16.67 & 22.22 & 16.67 & 100 \\
\hline $45-64$ & 16 & 30 & 42 & 12 & 100 & 32.20 & 16.95 & 25.42 & 27.12 & 100 \\
\hline$>64$ & 10 & 23.33 & 40 & 26.67 & 100 & 19.44 & 16.67 & 33.33 & 30.56 & 100 \\
\hline \multicolumn{11}{|l|}{ GENDER } \\
\hline Male* & 5.4 & 45.9 & 37.8 & 10.8 & 100 & 38.8 & 14.3 & 18.4 & 28.6 & 100 \\
\hline Female & 22.2 & 19.0 & 39.7 & 19.0 & 100 & 23.1 & 18.5 & 33.8 & 24.6 & 100 \\
\hline
\end{tabular}

* Male $v s$. Female, $\mathrm{p}=0.012$ 
The symptoms of CVD are extremely variable and negatively impacting the quality of life, where the selfreported symptoms are worse in women and the prevalence increases with age [9, 35]. Gender is considered as an important factor in self-medication patterns [8]. The all surveyed respondents most frequently used products based on aescin both for oral and topical use. There was no statistically significant difference between the age groups of respondents on the choice of venoactive drugs for oral or topical use. In the group of self-initiative respondents included in the research, male patients significantly more frequently used products based on Ginkgo biloba extracts for oral use $(\mathrm{p}=0.012)$, while there was no difference in the choice of the topical preparation with respect to sex (Table III). In Serbia, medicines based on Ginkgo biloba extracts are commonly available in the pharmacy (effective in preventing cognitive decline, vascular and tissue protection), but influence of television, radio, the internet and patient brochures containing information about Ginkgo biloba may explain obtained result from our research. Although self-medication has a positive impact on individual health and the health care system in general, irrational self-medication practice may increase health risks including: suboptimal therapy, misdiagnosis, interactions, adverse drug reactions, and polypharmacy [19]. Negative outcomes and potential risk of self-medication in patients with chronic venous diseases in our case are probably suboptimal pharmacotherapy in patients with self-initiated use of venoactive medicines for the symptoms of CVD.

\section{Conclusions}

The results of the survey indicated that self-medication practice is a common experience in the population of patients with chronic venous disease. The choice of venoactive drugs according to the route of administration and nature of the preparation differed significantly between health professionals and patients opting for self-initiated use of medications. Therefore, the role of physicians and pharmacists is indispensable and very important and it comprises advising patients to opt for a parallel use of oral and topical venoactive medications thus obtaining the best therapeutic effects. According to this, it is important to have data on selfmedication in this area, so that future interventions can be planned.

\section{Acknowledgement}

The study was supported by the Ministry of Science and Technological Development of the Republic of Serbia (Project No 43012, III 41017). The authors would like to thank to pharmacists from the Remedia for their help and support in the data collection and their collaborated efforts in conducting the survey.

\section{Conflict of interest}

The authors declare no conflict of interest.

\section{References}

1. Abdualkader AM, Ghawi AM, Alaama M, Leech therapeutic applications. Indian J Pharm Sci., 2013; 75(2): 127-137.

2. Al Shammeri O, AlHamdan N, Al-hothaly B, Midhet F, Hussain M, Al-Mohaimeed A, Chronic Venous Insufficiency: prevalence and effect of compression stockings. Int J Health Sci (Qassim), 2014; 8(3): 231-236.

3. Alghanim SA, Self-medication practice among patients in a public health care system. East Medit Health J., 2011; 17(5): 409-416.

4. Antignani PL, Medical Treatment of Chronic Venous Disease. SM J Pharmac Ther., 2017; 3(1): 1015: 1-8.

5. Barański K, Chudek J, Factors affecting patients' selfmanagement in chronic venous disorders: a singlecenter study. Patient Prefer Adherence, 2016; 10: 1623-1629.

6. Belczak SQ, Sincos IR, Campos W, Beserra J, Nering G, Aun R, Veno-active drugs for chronic venous disease: A randomized, double-blind, placebocontrolled parallel-design trial. Phlebology, 2014; 29(7): 454-460.

7. Bennadi D, Self-medication: A current challenge. $J$ Basic Clin Pharm., 2014; 5(1): 19-23.

8. Bhardwaj BR, Sayedda K, Ahmed QS, Analysis of self medication practice among medical undergraduates: a study in tertiary care teaching hospital, Bareilly. Int J Basic Clin Pharmacol., 2017; 6(4): 827-831.

9. Branisteanu DE, Feodor T, Baila S, Mitea IA, Vittos $\mathrm{O}$, Impact of chronic venous disease on quality of life: Results of vein alarm study. Exp Ther Med., 2019; 17(2): 1091-1096.

10. Carrasco-Garrido P, Jiménez-García R, Barrera VH, Gil de Miguel A, Predictive factors of self-medicated drug use among the Spanish adult population. Pharmacoepidemiol Drug Saf., 2008; 17(2): 193-199.

11. Corrêa da Silva MG, Soares MC, Muccillo-Baisch $\mathrm{AL}$, Self-medication in university students from the city of Rio Grande, Brazil. BMC Public Health, 2012; 12: 339: 1-7.

12. D'alessandro A, Caroli A, D'alessandro A, Mandolesi D, Venosi S, Orsini A, Riva A, Morazzoni P, Balbo A, Mandolesi S, Use of Ginkgo biloba phytosome in chronic venous disease: a pilot study. Acta Phlebologica, 2015; 16(2): 83-92.

13. Damnjanovic I, Kitic D, Stefanovic N, ZlatkovicGuberinic S, Catic-Djordjevic A, Velickovic-Radovanovic $\mathrm{R}$, Herbal self-medication use in patients with diabetes mellitus type 2. Turk J Med Sci., 2015; 45(4): 964-971.

14. Dudek-Makuch M, Studzinska-Sroka E, Horse chestnut efficacy and safety in chronic venous insufficiency: an overview. Revista Brasileira de Farmacognosia, 2015; 25: 533-541.

15. Eklof B, Perrin M, Delis KT, Rutherford RB, Gloviczki $\mathrm{P}$, Updated terminology of chronic venous disorders: The VEIN-TERM transatlantic interdisciplinary consensus document. J Vasc Surg., 2009; 49(2): 498-501.

16. Garg N, Gloviczki P, Chronic Venous Insufficiency, In: Creager MA, Beckman JA, Loscalzo J, eds. 
Vascular Medicine: A Companion to Braunwald's Heart Disease. $2^{\text {nd }}$ ed. Philadelphia, PA: Elsevier Saunders; 2013 chap 55.

17. Garofalo L, Di Giuseppe G, Angelillo IF, Selfmedication practices among parents in Italy. Biomed Res Int., 2015; 2015: 580650: 1-8.

18. Gohel MS, Davies AH, Pharmacological agents in the treatment of venous disease: an update of the available evidence. Curr Vasc Pharmacol., 2009; 7(3): 303-308

19. Hughes $\mathrm{C}$, McElnay M, Fleming J, Benefits and risks of self medication. Drug Saf., 2001; 24(14): 10271037.

20. Jantet G, Chronic venous insufficiency: worldwide results of the RELIEF study. Reflux assEssment and quaLity of life improvement with micronized Flavonoids. Angiology, 2002; 53(3): 245-256.

21. Keshari SS, Kesarwani P, Mishra M, Prevalence and pattern of self-medication practices in rural area of Barabanki. Indian J Clin Pract., 2014; 25(7): 636-639.

22. Maronea EM, Volontéb M, Limonic C, Petrinid O, Chiesa R, Therapeutic options and patterns of prescription in chronic venous disorders: results of a 3-year survey in Italy. Eur J Vasc Endovasc Surg., 2009; 38(4): 511-517.

23. McArdle M, Hernandez-Vila EA, Management of Chronic Venous Disease. Tex Heart Inst J., 2017; 44(5): 347-349.

24. Nicolaides A, Kakkos S, Eklof B, Perrin M, Nelzen O, Neglen P, Partsch H, Rybak Z, Management of chronic venous disorders of the lower limbs - guidelines according to scientific evidence. Int Angiol., 2014; 33(2): 87-208

25. Perrin M, Ramelet AA, Pharmacological treatment of primary chronic venous disease: rationale, results and unanswered questions. Eur J Vasc Endovasc Surg., 2011; 41(1): 117-125.
26. Ramelet AA, Boisseau MR, Allegra C, Nicolaides A, Jaeger K, Carpentier P, Cappelli R, Forconi S, Venoactive drugs in the management of chronic venous disease: An international consensus statement: current medical position, prospective views and final resolution. Clin Hemorheol Microcirc., 2005; 33(4): 309-319.

27. Ramelet AA, Kern P, Perrin M, Varicose veins and telangiectasias. Paris: Elsevier; 2004.

28. Ruiz ME, Risks of Self-Medication Practices. Current Drug Safety, 2010; 5(4): 315-323.

29. Schweim H, Ullmann M, Media influence on risk competence in self-medication and self-treatment. Ger Med Sci., 2015; 13: Doc10: 1-14.

30. Sherazi BA, Mahmood KT, Amin F, Zaka M, Riaz M, Javed A, Prevalence and Measure of Self Medication: A Review. J Pharm Sci Res., 2012; 4(3): 1774-1778.

31. Staffa R, Chronic venous insufficiency - epidemiology. Bratisl Lek Listy., 2002; 103(4-5): 166-168.

32. Suter A, Bommer S, Rechner J, Treatment of patients with venous insufficiency with fresh plant horse chestnut seed extract: a review of 5 clinical studies. Adv Ther., 2006; 23(1): 179-190.

33. Urbanek T, Dorobisz A, Gabriel M, Hendiger W, Jawień A, Kucharzewski M, Madycki G, Rybak Z, Staszkiewicz W, Zubilewicz T, Ziaja K, Assessment of public awareness in the field of epidemiology, prevention and treatment of chronic venous diseases in Poland. Phlebological Rev., 2015; 23(2): 45-53.

34. Vecchio C, Frisinghelli A, Topically applied heparins for the treatment of vascular disorders: a comprehensive review. Clin Drug Investig., 2008; 28(10): 603-614.

35. Wittens C, Davies AH, Bækgaard N, European Society for Vascular Surgery. Editor's Choice - Management of Chronic Venous Disease: Clinical Practice Guidelines of the European Society for Vascular Surgery (ESVS). Eur J Vasc Endovasc Surg., 2015; 49(6): 678-737. 